\title{
sciendo
}

\section{Marketing communication tools and their influence on marketing innovation: Evidence from Slovakian SMEs}

\author{
Mehmet CIVELEK \\ University of Entrepreneurship and Law, Ostrava, Czech Republic \\ m_civelek@windowslive.com \\ Michal ČERVINKA \\ University of Entrepreneurship and Law, Ostrava, Czech Republic \\ Krzysztof GAJDKA \\ University of Entrepreneurship and Law, Prague, Czech Republic \\ Václav NÉTEK \\ University of Entrepreneurship and Law, Ostrava, Czech Republic
}

\begin{abstract}
Due to lack of sources, SMEs face certain problems when applying innovative activities. Since marketing communication tools enable to perform innovative actions, SMEs' usage of such channels might provide solutions for them to overcome the barriers of making innovation. Thus, this paper investigates whether the usage of marketing communication tools by SMEs enables them to be innovative in marketing or not, and the research question is "Does the usage of marketing communication tools by SMEs improve their innovativeness in marketing?" This paper focuses on traditional and technology-enabled marketing communication tools, such as direct marketing, personal selling, online marketing, and advertising in social media. The researchers employ a random sampling method and then create an online internet-mediated questionnaire to collect data from 812 SMEs in Slovakia. The researchers have also performed Ordinal Logistic Regression analyses to fulfill the research aim. The results show that the usage of marketing communication tools by SMEs improves their innovative posture in marketing. The education level of firm executives and cultural factors in a specific nation might be the reasons for the findings of this research. Thus, the trainings and financial support provided by policymakers and collaboration of other institutions are beneficial for the growth of SMEs. This research analyzes traditional and technology-enabled marketing tools, and areas of marketing innovation in a broad perspective, including innovations in products/services, prices, distribution, promotion, people, processes, and visualization. Therefore, it differs from other studies and fills the research gap by making a significant value addition in related literature.
\end{abstract}

Keywords: marketing communication tools, marketing innovation, innovation, SMEs, Slovakia, traditional marketing communication tools, technology-enabled marketing communication tools.

Please cite the article as follows: Civelek, M., Červinka,M., Gajdka, K., Nétek, V. (2021)," Marketing communication tools and their influence on marketing innovation: Evidence from Slovakian SMEs", Management \& Marketing. Challenges for the Knowledge Society, Vol. 16, No. 3, pp. 210-227, DOI: 10.2478/mmcks-2021-0013. 


\section{Introduction}

Compared to their larger rivals, SMEs lack standardized products for domestic and international markets (Amoah et al., 2021) and are more likely to face bankruptcy issues (Dvorsky et al., 2021). In this context, innovative actions in their marketing operations might be beneficial for them to be more competitive (Cuevas-Vargas et al., 2021; Kubickova et al., 2021) and to have more profits in the long term (Pisicchio \& Toaldo 2020). Regarding innovative actions in marketing, they include changes or improvements in the following areas: product, price, promotion, and distribution that stimulate firms' sales (Falcones \& Castilla 2020). In addition, there are also other areas of marketing such as people, visualization (Cermak \& Reznicek, 2014), and process (Falcones \& Castilla 2020) that increase the performance of firms by fulfilling the demands of their customers.

However, innovative changes and improvements in marketing, namely, product, price, promotion, distribution, people, process, and visualizations, might stem from SMEs' marketing communication tools. This is because the developments via internet platforms (Horvath et al., 2021) and digital transformation have forced businesses to implement new strategies for their operations that stimulate firms' innovative activities (Ziółkowska, 2021). For instance, in terms of technology-enabled marketing communication, social media has become a trendy communication tool that enables firms to explore and find opportunities (Dima \& Vasilache, 2015; Tekin \& Turhan, 2020), thus improving firms' innovativeness (Papa et al., 2018). Furthermore, social media platforms also make businesses create new goods and services and improve their quality (Wardati \& Mahendrawathi, 2019). Moreover, communication tools improve the marketing performance of enterprises (Pisicchio \& Toaldo 2020). Therefore, this paper explores the impact of the usage of traditional and technology-enabled marketing communication tools on the innovations of marketing.

Concerning the traditional marketing communication tools, they include offline marketing communication, offline promotion, and advertising activities via traditional media channels, such as television, radio, print, newspapers (Ramasobana et al., 2017), pamphlets, posters business cards (Kallier, 2017), magazines, posters, brochures and billboard (Cant \& Wiid, 2016), other channels such as sales promotion, personal sales, public relations, sponsorship (Ramasobana et al., 2017), exhibitions, trade fairs and direct marketing (Amirkhanpour et al., 2014). Thus, this paper also considers the tools mentioned above as traditional marketing communication tools.

Regarding the details of technology-enabled marketing communication tools, platforms enable its users to perform online mobile marketing (SMS, MMS, etc.) (Kallier, 2017; Amirkhanpour et al., 2014), social media (Facebook, Instagram, etc.), content marketing (Taiminen \& Karjaluoto, 2015), viral marketing and word-of-mouth (WOM) activities (Ramasobana et al., 2017). For instance, smartphones, tablets, and personal computers enable businesses to perform their online marketing activities since firms can send e-mails, SMS, MMS, voice messages by such vehicles (Amirkhanpour et al., 2014). Moreover, firms can perform marketing activities via their websites (Kallier, 2017), other blogs, forums, social media accounts (Facebook, Twitter, Instagram, Reddit, Linkedin, Pinterest, etc.) (Taiminen \& Karjaluoto, 2015), mobile applications, and quick response (QR) codes (Amirkhanpour et al., 2014). In this regard, this paper also reckons in tools mentioned above as technology-enabled marketing communication tools. 
Although some studies analyze the impact of the usage of marketing communication tools on some areas of marketing innovation (Falcones \& Castilla, 2020; Panasenko et al., 2021; Fraccastoro et al., 2020; Cermak \& Reznicek, 2014), this paper includes various areas of marketing innovations including innovations of SMEs in products/services, prices, distribution, promotion, people, processes, and visualization. Moreover, some studies (Kallier, 2017; Malesev \& Cherry, 2021) compare the usage of traditional (offline) and technology-enabled (online) marketing tools of SMEs, and some others analyze the effects of these tools on brand performance (Luxton et al., 2015; Falcones \& Castilla 2020) and customer acquisition (Fraccastoro et al., 2021). However, in contrast with these studies, this paper analyzes marketing communication tools from a widened scope by including both traditional and technology-enabled marketing tools into the research and focuses on the innovativeness of businesses in marketing. In this context, the research question that the authors try to answer is as follows: "Does the usage of marketing communication tools by SMEs improve their innovativeness in the areas of marketing?". Since the answer to this research question fills the gap in the literature and makes significant value addition, policymakers, academicians, and firms might be interested in answering this research question and this value-creating research.

The rest of the paper is structured as follows: Section 1 focuses on the theoretical basis of the research by presenting the development of the research hypotheses. Methodological approaches and the details about data will be presented in Section 2 . Section 3 clearly expresses the results of the paper. The authors discuss the main results and propose some reasons for the results with policy implications in Section 4. Finally, section 5 concludes the most critical points of this research with theoretical-managerial implications, limitations of the paper and recommendations for future research.

\section{Literature review}

The first area of marketing innovation, namely product/service innovation, consists of certain innovative activities that enable businesses to introduce new products and services (Matúš et al., 2015). Furthermore, innovations in services and products satisfy customers' expectations (Khan et al., 2021), increasing firms' competitiveness (Kovanoviene et al., 2021). In this regard, the effectiveness in using marketing communication tools determines the performance of businesses regarding their product innovation process (Zaušková et al., 2015).

Similarly, Falcones and Castilla (2020) also express the fact that marketing strategies affect service innovation. Robul et al. (2020) also state that, when using traditional marketing tools with digital marketing channels, creating new goods becomes accelerated. For instance, social networks are technology-enabled marketing tools that motivate users to develop new goods and services (Chia-Liang, 2018). By analyzing firms in the tourism industry, Barna and Semak (2020) declare that the usage of modern technologies in marketing tools by firms enables firms to draw their customers' attention to purchase a tour, and it positively affects customer royalty, brand image, and revenues of firms. Since some traditional marketing communication tools enable businesses to have face-to-face interactions with their customers, firms also notice their customers' needs and problems that improve or develop their goods and services. For these reasons, the first research hypotheses are created, as follows: 
H1a: The usage of traditional marketing communication tools positively affects innovations in products/services.

H1b: The usage of technology-enabled marketing communication tools positively affects innovations in products/services.

When consumers are willing to buy products or services, the price of these goods is one of the main factors determining their purchasing decisions (Zaušková et al., 2015). This is because consumers are sensitive to prices. In this regard, when firms make reductions in their products or services prices (Kizim et al., 2019) and implement effective pricing strategies, they receive competitive advantages against their rivals (Melnyk \& Golysheva, 2017). Since digital tools enable business users to reduce their costs, firms can lower their prices (Kizim et al., 2019). Therefore, the usage of technology-enabled marketing communication tools by firms positively affects their pricing strategies and methods. Concerning traditional tools such as personal sales, face-to-face interactions motivate firms to find innovative solutions in their pricing strategies. This is because salespeople become informed about their rivals' prices and become motivated to provide certain promotions for their customers. These arguments lead to the creation of other hypotheses, as follows:

H2a: The usage of traditional marketing communication tools positively affects innovations in prices.

$\mathrm{H} 2 \mathrm{~b}$ : The usage of technology-enabled marketing communication tools positively affects innovations in prices.

Distribution is one of the essential primary activities in the value chain of businesses (Milichovský, 2017). The success of firms regarding the distribution of their products also increases their competitiveness. For instance, the technologies and methods that Amazon follows are some of the main reasons why this company plays a leading role in its sector (Kizim et al., 2019). The distribution process consists of the movement of goods from producer to buyer, and it is a part of the marketing strategies of firms. This process consists of various firm activities such as planning, organization, management, and control, since it has different stages, including packaging, storage, handling, and transportation. Therefore, marketing communication channels can affect the distribution process since these channels increase the sales, demand for products, and transportation operations (Bilovodska, 2017).

Furthermore, according to Panasenko et al. (2021), innovative activities in new technologies positively affect the distribution process of firms. Similarly, using traditional marketing communication tools can also enable businesses to improve their distribution processes and implement new distribution strategies to satisfy customers' needs. Such evidence leads to setting other hypotheses, as follows:

H3a: The usage of traditional marketing communication tools positively affects innovations in distribution.

H3b: The usage of technology-enabled marketing communication tools positively affects innovations in distribution.

When creating a marketing plan, promotion is another factor to consider for businesses (Robul et al., 2020). This is because firms that are willing to compete with their rivals need to make promotions for their goods and services (Efremenko et al., 2020). Furthermore, businesses benefit from marketing communication channels when making such promotions (Efremenko et al., 2020; Robul et al., 2020; Melnyk \& Golysheva, 2017). This is because innovations in promotion also depend on communication channels that businesses use for their marketing strategies. In this regard, the websites of businesses are 
good examples of practical communication tools since such channels make businesses actively manage their promotion strategies (Kurcheeva \& Bakaev, 2017). Thus, other research hypotheses might be presented as follows:

H4a: The usage of traditional marketing communication tools positively affects innovations in promotion.

$\mathrm{H} 4 \mathrm{~b}$ : The usage of technology-enabled marketing communication tools positively affects innovations in promotion.

Website, online advertisements, videos, blogs, and social media platforms that are the technology-enabled marketing tools have been new tools for businesses when managing their customer relationships (Armstrong et al., 2017; Chia-Liang, 2018). These channels enable users to share their experiences and comments about goods and services and the quality of these tools (Armstrong et al., 2017). Therefore, customers' comments might affect potential consumers' purchase decisions and stimulate firms to have closer interactions with their customers (Chia-Liang, 2018; Dima \& Ghinea, 2016; Pisicchio \& Toaldo 2020). These channels also play crucial roles in value creation, thus, they increase firm competitiveness by reducing costs (Panasenko et al., 2021). Similarly to technologyenabled marketing communication tools, traditional marketing communication tools also carry high importance for customer relationship management when interacting with people (Fraccastoro et al., 2021). The empirical results of the studies mentioned above result in other research hypotheses, as follows:

H5a: The usage of traditional marketing communication tools positively affects innovations in the people's factor.

H5b: The usage of technology-enabled marketing communication tools positively affects innovations in the people's factor.

Innovations in firm processes also determine the competitiveness of businesses (Zaušková et al., 2015). Process innovation is related to the introduction of a new product or service, and is related to other activities, such as market research and marketing tools that fulfill customers' needs. Initiatives of firms regarding process innovation have benefits on all processes and procedures of firms (Falcones \& Castilla 2020), since they increase the satisfaction of customers (Matús et al., 2015). The marketing strategies that businesses apply also determine process innovation (Falcones \& Castilla 2020). Therefore, the usage of marketing communication tools can also motivate all organizational processes of firms (Luxton et al., 2015; Pisicchio \& Toaldo, 2020). Thus, the researchers formulate other hypotheses, as presented below:

H6a: The usage of traditional marketing communication tools positively affects innovations in processes.

H6b: The usage of technology-enabled marketing communication tools positively affects innovations in processes.

Visualization enables businesses to provide information about their product and services; thus, its understanding and simplicity are essential factors for the marketing activities of firms. When firms send quality and attractive signals via visualization regarding their goods, they can draw their customers' attention. In this regard, practical usage of marketing tools and strategies might stimulate visualization quality (Cermak \& Reznicek, 2014). Numerous researchers (Robul et al., 2020; Fraccastoro et al., 2021) also highlight that visualization depends on innovative technologies such as the usage of social media channels. This is because social media platforms increase the visibility of businesses and 
include essential information about businesses. Concerning traditional marketing communication channels, TV ads or other channels, such as billboards, they present signs, knowledge, or other details about businesses. Hence, depending on their customers' reactions to those images or signs, businesses can change their visualization strategies that create innovative solutions for businesses. By considering above mentioned arguments, the researchers set other hypotheses, as follows:

H7a: The usage of traditional marketing communication tools positively affects innovations in visualization.

H7b: The usage of technology-enabled marketing communication tools positively affects innovations in visualization.

\section{Methodology and Data \\ Sample and Data Collection}

This research aims to find out the influences of the usage of traditional and technologyenabled marketing tools by SMEs on marketing innovation activities consisting of innovations in product/service, price, distribution, promotion, people, process, and visualization. These variables are the dependent variables of the research models, while traditional and technology-enabled marketing communication tools are the independent variables. The researchers have created an online internet-mediated questionnaire to collect the data. Regarding the sample selection, the researchers apply a random sampling method, and the sample consists of 812 Slovakian SMEs. The authors have sent the questionnaire link to the randomly selected respondents who are the executives of the enterprises. The online questionnaire link is found at: https://docs.google.com/forms/d/e/1FAIpQLSeTBISi1VavWYjic8 vcwbCkABTT5C8n32yR kDnquZzAUisXA/formResponse. The data collection process started in April 2020 and was completed in January 2021.

Table 1 below presents the characteristics of the survey respondents and SMEs. The SMEs that the research sample includes are located in various regions of Slovakia. These businesses operate under various sectors, including service, agriculture, manufacturing, retail, information technology, automotive, construction, energy, education, financial services, real estate, and transportation. While 363 respondents are company executives, other 449 respondents are owners of the analyzed SMEs.

Table 1. Sample profile

\begin{tabular}{|c|c|c|c|}
\hline & & $n$ & Share \\
\hline \multirow{4}{*}{ Firm size } & micro & 392 & $48.28 \%$ \\
\hline & small & 291 & $35.84 \%$ \\
\hline & medium & 129 & $15.88 \%$ \\
\hline & Total & 812 & $100 \%$ \\
\hline \multirow{3}{*}{ Firm age } & up to 5 years & 419 & $51.60 \%$ \\
\hline & 5 years and more & 393 & $48.40 \%$ \\
\hline & Total & 812 & $100 \%$ \\
\hline \multirow{5}{*}{ Legal Structure } & sole prop. & 123 & $15.15 \%$ \\
\hline & Ltd. & 595 & $73.28 \%$ \\
\hline & PLC & 58 & $7.14 \%$ \\
\hline & other & 36 & $4.43 \%$ \\
\hline & Total & 812 & $100 \%$ \\
\hline
\end{tabular}




\begin{tabular}{|c|c|c|c|}
\hline \multirow{3}{*}{$\begin{array}{l}\text { Respondents' } \\
\text { gender }\end{array}$} & female & 421 & $51.85 \%$ \\
\hline & male & 391 & $48.15 \%$ \\
\hline & Total & 812 & $100 \%$ \\
\hline \multirow{3}{*}{$\begin{array}{l}\text { Respondents' } \\
\text { age }\end{array}$} & less than 30 & 547 & $67.36 \%$ \\
\hline & 30 and more & 265 & $32.64 \%$ \\
\hline & Total & 812 & $100 \%$ \\
\hline \multirow[t]{2}{*}{$\begin{array}{l}\text { Respondents' } \\
\text { job status }\end{array}$} & $\begin{array}{l}\text { owners } \\
\text { executives }\end{array}$ & $\begin{array}{l}449 \\
363\end{array}$ & $\begin{array}{l}55.29 \% \\
44.71 \%\end{array}$ \\
\hline & Total & 812 & $100 \%$ \\
\hline \multirow{2}{*}{$\begin{array}{l}\text { Respondents' } \\
\text { educational } \\
\text { status }\end{array}$} & $\begin{array}{l}\text { at least bachelor's } \\
\text { less than bachelor }\end{array}$ & $\begin{array}{l}424 \\
388\end{array}$ & $\begin{array}{l}52.22 \% \\
47.78 \%\end{array}$ \\
\hline & Total & 812 & $100 \%$ \\
\hline
\end{tabular}

On the other hand, this research employs Cochran's formula (Cochran, 1963), which is presented below in Equation 1, to calculate sample volume. As mentioned in previous studies, the sampling error is $5 \%(e=0.05)$; thus, the confidence level is $95 \%$. Since the sample population is large (SMEs in Slovakia), variability is considered as 0.5 (maximum variability $\mathrm{p}=0.5$ ), and $\mathrm{q}$ is $1-\mathrm{p}$, i.e., 0.5 . When putting these volumes into Cochran's formula (1963);

$\mathrm{n}=$ sample size

$\mathrm{Z}=$ confidence level at $95 \%$ (the value of 1.96 is gained by statistical tables that include field below the normal curve)

$$
\begin{gathered}
n_{0}=\frac{Z^{2}(p)(q)}{(e)^{2}}[1] \\
n_{0}=\frac{1.96(0.5)(0.5)}{(0.05)^{2}}=384[2]
\end{gathered}
$$

The result from the Cochran formula indicates that the required sample size is 384 . Since the research sample includes 812 SMEs, this sample size is adequate to perform ordinal logistic regression analyses.

\section{Methods and measures}

Concerning the evaluation of dependent variables, the researchers address the following question to the prospective respondents: "In which marketing area is innovation most evident in your business?". First, in terms of areas that are the independent variables of the research models, the options for the survey respondents are as follows: "product/service, price, distribution, promotion, people, process and visualization." Then, the researchers employ the Five Point Likert Scale to measure the responses from this question as follows "1-least significant to 5-most significant". Thus, higher volumes indicate higher innovative actions in these marketing areas.

To evaluate the usage of traditional and technology-enabled marketing communication tools by SMEs, the researchers include the following question into the questionnaire: "In which communication tool of marketing communication is innovation most evident in your business?". Then, the researchers present some prospective answers to this question, including some tools of both traditional and technology-enabled communication. Regarding traditional tools, the options are: "PR/Public relations, sales 
promotion, direct marketing, personal selling/face to face communication, sponsoring, exhibitions/trade shows and advertising in the traditional media (print....)". The options for technology-enabled marketing communication tools are "online marketing/internet, advertising social media, content marketing/social media, mobile marketing (SMS, MMS...), viral marketing, WOM, a chatbot (Facebook-MSN)". The researchers use the Five-Point Likert Scale to scale the responses "1-least significant to 5-most significant". Ultimately, the researchers separately combine the responses for traditional and technology-enabled marketing tools to get average scores for the usage of these channels by SMEs.

Due to having ordinal dependent variables (scaled by five-point Likert scale) and categorical and ranked independent variables, the scholars apply Ordinal Logistic Regression Analyses via SPSS Statistical Software. As already mentioned, the dependent variables of the research models have five categories from 1-least significant to 5-most significant. However, the researcher assumes that the respondents rank these options with higher volumes. Thus, when running Ordinal Logistics Regression analyses, the logit function is applied by the researchers.

When it comes to the presentation of basic logit Ordinal Logistic Regression models, they can be illustrated as follows:

$$
\operatorname{Logit}(P(Y \leq j))=\beta_{j 0}+\beta_{j 1} X_{1}+\beta_{j 2} X_{2}
$$

$\mathrm{Y}=$ Ordinal outcome $\left(\mathrm{Y}_{1}\right.$ : product/service for Model 1, $\mathrm{Y}_{2}$ : price, $\mathrm{Y}_{3}$ : distribution, $\mathrm{Y}_{4}$ : promotion, $Y_{5}$ :people, $Y_{6}$ :process, $Y_{7}$ : visualization)

$\mathrm{J}=$ categories

$\mathrm{X}_{1}$ - Independent variable (X1: usage of traditional marketing communication tools, same for all research models)

$\mathrm{X}_{2}$ - Independent variable (X2: usage of technology-enabled marketing communication tools, same for all research models)

$\mathrm{B}_{1}$ - Regression coefficients

$\beta_{0}-$ Constant or intercept term.

P- predictor

In relation to the assumptions of Ordinal Logistic Regression Tests, this research considers Model Fitting, Goodness of Fit and Test of Parallel Lines information. In this regard, the results for these indicators are illustrated below, in Table 2. Under the column of Model Fitting, there are two indicators, namely, -2 Log Likelihood and Chi Square that represent whether a significant improvement exists in overal model fit or not. As illustrated in Table 2, all $\mathrm{p}$ values for the research models are significant at $5 \%$ level of significance. Thus, the results present strong evidences to indicate the statistically signifant improvements in the final models comparing to null models. Furthermore, the results indicate the fact that the created research models fit with the data and represent good model fit (Model 1=, $\chi^{2}(2)=437.363$, Sig, $p<0.05$; Model 2 $=. \chi^{2}(2)=398.917$, Sig, $p<0.05$; Model 3 $=\chi^{2}(2)=437.556$, Sig, $p<0.05$; Model $4=\chi^{2}(2)=598.619$, Sig, $p<0.05$; Model $5=$ $\chi^{2}(2)=504.280$, Sig, $p<0.05$; Model $=\chi^{2}(2)=456.023$, Sig, $p<0.05$; Model $7=\chi^{2}(2)=$ 485.246, Sig, $\mathrm{p}<0.05)$. 
Table 2. Model fitting, Pseudo R-square, Test of parallel lines

\begin{tabular}{|c|c|c|c|c|c|c|}
\hline \multirow{2}{*}{\begin{tabular}{|l} 
Assumptions \\
Models
\end{tabular}} & Model fitting & \multicolumn{2}{|c|}{$\begin{array}{l}\text { Goodness of fit } \\
\text { Pseudo R-square }\end{array}$} & \multicolumn{3}{|c|}{ Test of parallel lines } \\
\hline & \begin{tabular}{|c|}
-2 Log Chi- \\
likelihood Square df Sig.
\end{tabular} & $\begin{array}{r}\text { Cox \& } \\
\text { Snell }\end{array}$ & Nagelkerke & \begin{tabular}{|c|}
-2 Log \\
likelihood
\end{tabular} & $\begin{array}{l}\text { Chi- } \\
\text { Square df }\end{array}$ & Sig. \\
\hline Model 1 & 1252.154437 .36320 .000 & 0.417 & 0.448 & 1692.703 & 9.0356 & 0.154 \\
\hline Model 2 & 1560.600398 .91720 .000 & 0.389 & 0.08 & 1763.913 & $9.324 \quad 6$ & 0.176 \\
\hline Model 3 & 1485.574437 .55620 .000 & 0.417 & 0.437 & 1573.478 & 9.2356 & 0.116 \\
\hline Model 4 & 1344.773598 .61920 .000 & 0.522 & $0 ., 549$ & 1644.773 & 15.4936 & 0,072 \\
\hline Model 5 & 1457.633504 .28020 .000 & 0.463 & 0.485 & 1822.334 & 18.1926 & 0.262 \\
\hline Model 6 & 1537.003456 .02320 .000 & 0.430 & 0.450 & 1712.863 & 14.6546 & 0.163 \\
\hline Model 7 & 1414.332485 .24620 .000 & 0.450 & 0.473 & 1442.026 & $5.428 \quad 6$ & 0.542 \\
\hline
\end{tabular}

Source: Authors' own research results.

Note: Sig.: significance, $p$ value; df: Degree of freedom

Table 2 also illustrates Pseudo R-square consisting of Cox \& Snell and Nagelkerke Statistics, representing Goodness of Fit. The results from the statistics indicate the variability in the dependent variables when adding new, independent variables into the research models. Hence, adding traditional and technology-enabled marketing tools into the 1 st research model explains $44.8 \%$ variability in product/service innovation, which is the dependent variable of the first research model. In line with this fact, including traditional and technology-enabled marketing communication tools to other research models explains $40.8 \%$ to $54.9 \%$ of variability in the dependent variables of other models (Nagelkerke statistics for Model-2=0.402; Model-3=0.437; Model-4=0.549; Model-5= 0.485; Model-6=0.450; Model-7=0.473).

Another indicator in Table 2 is Test of Parallel Lines. This indicator signals if the slope coefficients are same between all the categories (4 cutoffs that the Likert scale has, from 1 to 5) of dependent variables. The underlying reason to consider this fact is Proportional Odds assumption. Similar with other analyses, the researchers also consider $5 \%$ level of significance. However, unlike other analyses, $\mathrm{p}$ values (Sig. column in the table) have to be higher than this significance level to check this assumption. Considering those $p$ values in the Test of Parallel Lines, they are all higher than the selected significance level (Model-1 $=\chi^{2}(6)=9.035, \mathrm{p}=0.154>0.05$; Model $-2=\chi^{2}(6)=9.324, \mathrm{p}=0.176>0.05$; Model $-3=$ $\chi^{2}(6)=9.235, \mathrm{p}=0.116>0.05 ;$ Model $-4=\chi^{2}(6)=15.493, \mathrm{p}=0.072>0.05 ;$ Model $-5=\chi^{2}(6)=$ 18.192, $\mathrm{p}=0.262>0.05$; Model $-6=\chi^{2}(6)=14.654, \mathrm{p}=0.163>0.05$; Model $-7=\chi^{2}(6)=5.428$, $\mathrm{p}=0.542>0.05$ ). These results check the assumptions of Ordinal Logistic Regression analyses, therefore, the usage of Ordinal Logistic Regression is suitable for the analyses within this research.

The researchers selected a 5\% significance level concerning hypothesis testing to support or reject research hypotheses. P values greater than this significance level means that the researchers will not support the research hypotheses, and will support the null hypotheses. Null hypotheses presume that there are no positive effects of the usage of traditional and technology-enabled marketing communication tools on innovations in areas of marketing. 


\section{Results}

The results of Ordinal Logistic Regression analyses regarding the first four models are presented below in Table 3. Ordinal regression includes an algorithm that calculates a continuous latent variable (Harrell, 2015). Due to having dependent variables calculated by the Five Points Likert Scale (1-least significant to 5-most significant), this algorithm shows the differences in 4 levels of the dependent variable. Therefore, four cut-offs are in existence in each dependent variable. In this regard, [Product/Service] = 1 indicates the cutoff value between the answers of 1 to 2 , [Product/Service] $=2$ means the cut-off value between 2 to 3, [Product/Service] = 3 illustrates the cut-off value between the answers of 3 to 4 and lastly, [Product/Service] $=4$ presents the cut-off value between 4 to 5 . Hence, when other items and covariates are zero, [Product/Service], $=1$ indicates a cutpoint representing the differences from 1-least significant to 2 . Since all dependent variables of the research models are calculated by the Five Points Likert Scale, they all have four cutpoints that represent the same values with the above-mentioned dependent variable, namely, Product/Service. These cutpoints or cut-offs are also presented in Table 3, as follows:

Table 3. The results of Ordinal Logistic Regression Tests regarding $1^{\text {st }}, 2^{\text {nd }}, 3^{\text {rd }}$, and $4^{\text {th }}$ models

\begin{tabular}{|c|c|c|c|c|c|c|}
\hline Variable & Estimate & S.E. & Wald & df & Sig. & $\begin{array}{c}95 \% \text { CI } \\
\text { [Lower Upper] }\end{array}$ \\
\hline \multicolumn{7}{|c|}{ MODEL-1 } \\
\hline Product $/$ service $=1$ & 1.803 & 0.188 & 92.031 & 1 & 0.000 & {$\left[\begin{array}{ll}1.435 & 2.172\end{array}\right]$} \\
\hline Product $/$ service $=2$ & 2.064 & 0.192 & 115.579 & 1 & 0.000 & {$\left[\begin{array}{ll}1.688 & 2.440\end{array}\right]$} \\
\hline Product $/$ service $=3$ & 2.885 & 0.207 & 193.522 & 1 & 0.000 & {$\left[\begin{array}{ll}2.478 & 3.291\end{array}\right]$} \\
\hline Product $/$ service $=4$ & 3.977 & 0.227 & 305.911 & 1 & 0.000 & {$\left[\begin{array}{ll}3.531 & 4.423\end{array}\right]$} \\
\hline Traditional & 0.913 & 0.092 & 98.586 & 1 & 0.000 & {$\left[\begin{array}{ll}0.733 & 1.093\end{array}\right]$} \\
\hline Tech. enabled & 0.431 & 0.083 & 26.645 & 1 & 0.000 & {$\left[\begin{array}{ll}0.267 & 0.594\end{array}\right]$} \\
\hline \multicolumn{7}{|c|}{ MODEL-2 } \\
\hline Price $=1$ & 1.942 & 0.189 & 105.234 & 1 & 0.000 & {$\left[\begin{array}{ll}1.571 & 2.313\end{array}\right]$} \\
\hline Price $=2$ & 2.623 & 0.200 & 171.709 & 1 & 0.000 & {$\left[\begin{array}{ll}2.230 & 3.015\end{array}\right]$} \\
\hline Price $=3$ & 3.913 & 0.223 & 308.621 & 1 & 0.000 & {$\left[\begin{array}{ll}3.476 & 4.349\end{array}\right]$} \\
\hline Price $=4$ & 5.574 & 0.252 & 488.472 & 1 & 0.000 & {$\left[\begin{array}{ll}5.080 & 6.069\end{array}\right]$} \\
\hline Traditional & 0.916 & 0.088 & 109.449 & 1 & 0.000 & {$\left[\begin{array}{ll}0.744 & 1.087\end{array}\right]$} \\
\hline Tech. enabled & 0.317 & 0.078 & 16.506 & 1 & 0.000 & {$\left[\begin{array}{ll}0.164 & 0.470\end{array}\right]$} \\
\hline \multicolumn{7}{|c|}{ MODEL-3 } \\
\hline Distribution $=1$ & 2.534 & 0.215 & 139.231 & 1 & 0.000 & {$\left[\begin{array}{ll}2.113 & 2.955\end{array}\right]$} \\
\hline Distribution $=2$ & 3.294 & 0.228 & 209.107 & 1 & 0.000 & {$\left[\begin{array}{ll}2.848 & 3.741\end{array}\right]$} \\
\hline Distribution $=3$ & 4.575 & 0.250 & 333.726 & 1 & 0.000 & {$\left[\begin{array}{ll}4.084 & 5.066\end{array}\right]$} \\
\hline Distribution $=4$ & 5.985 & 0.276 & 470.666 & 1 & 0.000 & {$\left[\begin{array}{ll}5.445 & 6.526\end{array}\right]$} \\
\hline Traditional & 0.987 & 0.091 & 118.787 & 1 & 0.000 & {$\left[\begin{array}{ll}0.809 & 1.164\end{array}\right]$} \\
\hline
\end{tabular}




\begin{tabular}{|c|c|c|c|c|c|c|}
\hline Tech. enabled & 0.355 & 0.079 & 20.224 & 1 & 0.000 & {$\left[\begin{array}{ll}0.200 & 0.509\end{array}\right]$} \\
\hline \multicolumn{7}{|c|}{ MODEL-4 } \\
\hline Promotion $=1$ & 2.930 & 0.231 & 160.951 & 1 & 0.000 & {$\left[\begin{array}{ll}2.477 & 3.382\end{array}\right]$} \\
\hline Promotion $=2$ & 3.513 & 0.242 & 209.891 & 1 & 0.000 & {$\left[\begin{array}{ll}3.038 & 3.988\end{array}\right]$} \\
\hline Promotion $=3$ & 4.962 & 0.273 & 330.228 & 1 & 0.000 & {$\left[\begin{array}{ll}4.427 & 5.497\end{array}\right]$} \\
\hline Promotion $=4$ & 6.434 & 0.300 & 459.524 & 1 & 0.000 & {$\left[\begin{array}{ll}5.846 & 7.022\end{array}\right]$} \\
\hline Traditional & 0.866 & 0.091 & 91.315 & 1 & 0.000 & {$\left[\begin{array}{ll}0.689 & 1.044\end{array}\right]$} \\
\hline Tech. enabled & 0.847 & 0.083 & 103.696 & 1 & 0.000 & {$\left[\begin{array}{ll}0.684 & 1.010\end{array}\right]$} \\
\hline
\end{tabular}

Source: Authors' own research results. Note: S.E.: Standard Error, df: Degree of freedom, CI: Confidence intervals

As it is presented in Table 3 , all the cut-offs $(1,2,3,4)$ for the dependent variables, product/service, price, distribution, and promotion, and the independent variables, traditional and technology-enabled marketing communication tools are significant at a 5\% level of significance (Sig. $=0.000<0.05$ ). For this reason, it can be stated that the usage of traditional and technology-enabled marketing communication tools by SMEs have positive influences on the following components of marketing innovation: product/service, price, distribution, and promotion. Concerning innovations in product/service, when there is a one-unit increase on the independent variable, namely traditional and technology-enabled marketing tools, there are predicted increases of 0.913 and 0.431 in the log-odds of being higher levels in product and service innovations. The volumes for price, distribution and promotion innovations are 0.916 and $0.317,0.987$ and $0.355,0.866$ and 0.847 , respectively, for a one-unit increase in the traditional and technology-enabled marketing communication tools. For instance, having a one-unit increase in traditional marketing communication tools, the predicted increases in the log odds of being higher levels in price, distribution, and promotion will be 0.916, 0.987, and 0.847, respectively. These results mean that SMEs with higher volumes in using traditional and technology-enabled marketing tools are more likely to have more innovations in product/service, price, distribution, and promotion. In other words, SMEs that apply traditionally and technology-enabled marketing tools become more likely to have more innovations in product/service, price, distribution, and promotion than their rivals. All those facts support $\mathrm{H} 1 \mathrm{a}, \mathrm{b}, \mathrm{H} 2 \mathrm{a}, \mathrm{b}, \mathrm{H} 3 \mathrm{a}, \mathrm{b}$, and $\mathrm{H} 4 \mathrm{a}, \mathrm{b}$ hypotheses that assume positive influences of the traditional and technology-enabled tools on the components of marketing innovation.

Table 4 is also depicted below to indicate the results of Ordinal Logistic Regression analyses for the $5^{\text {th }}, 6^{\text {th }}$, and $7^{\text {th }}$ research models. When considering significance volumes (represented as "Sig." in the table) of the independent variables, they are all significant at a $5 \%$ level of significance (Sig.<0.05). Thus, it can be interpreted that traditional and technology-enabled marketing communication tools are also significant predictors for innovations in people, process and visualization, as they are for the first four research models.

Table 4. The results of Ordinal Logistic Regression Tests regarding $5^{\text {th }}, 6^{\text {th }}$ and 7 th models

\begin{tabular}{|c|c|c|c|c|c|c|}
\hline Variable & Estimate & S.E. & Wald & df & Sig. & $\begin{array}{c}\text { 95\% CI } \\
\text { [Lower Upper] }\end{array}$ \\
\hline \multicolumn{6}{|c|}{ MODEL-5 } \\
\hline
\end{tabular}




\begin{tabular}{|c|c|c|c|c|c|c|}
\hline People $=1$ & 2.243 & 0.201 & 124.729 & 1 & 0.000 & {$\left[\begin{array}{ll}1,849 & 2,637\end{array}\right]$} \\
\hline People $=2$ & 3.080 & 0.216 & 202,643 & 1 & 0.000 & {$\left[\begin{array}{ll}2.656 & 3.504\end{array}\right]$} \\
\hline People $=3$ & 4.328 & 0.240 & 324.442 & 1 & 0.000 & {$\left[\begin{array}{ll}3.857 & 4.799\end{array}\right]$} \\
\hline People $=4$ & 5.653 & 0.263 & 461.496 & 1 & 0.000 & {$\left[\begin{array}{ll}5.138 & 6.169\end{array}\right]$} \\
\hline Traditional & 1.102 & 0.091 & 146.173 & 1 & 0.000 & {$\left[\begin{array}{ll}0.923 & 1.280\end{array}\right]$} \\
\hline Tech. enabled & 0.370 & 0.079 & 21.843 & 1 & 0.000 & {$\left[\begin{array}{ll}0.215 & 0.525\end{array}\right]$} \\
\hline \multicolumn{7}{|c|}{ MODEL-6 } \\
\hline Process $=1$ & 2.039 & 0.193 & 111.800 & 1 & 0.000 & {$\left[\begin{array}{ll}1.661 & 2.417\end{array}\right]$} \\
\hline Process $=2$ & 2.899 & 0.208 & 194.702 & 1 & 0.000 & {$\left[\begin{array}{ll}2.492 & 3.306\end{array}\right]$} \\
\hline Process $=3$ & 4.324 & 0.234 & 342.482 & 1 & 0.000 & {$\left[\begin{array}{ll}3.866 & 4.782\end{array}\right]$} \\
\hline Process $=4$ & 5.591 & 0.255 & 479.541 & 1 & 0.000 & {$\left[\begin{array}{ll}5.091 & 6.092\end{array}\right]$} \\
\hline Traditional & 1,147 & 0.092 & 156.546 & 1 & 0.000 & {$\left[\begin{array}{ll}0.967 & 1.327\end{array}\right]$} \\
\hline Tech. enabled & 0.185 & 0.079 & 5.489 & 1 & 0.019 & {$\left[\begin{array}{ll}0.030 & 0.340\end{array}\right]$} \\
\hline \multicolumn{7}{|c|}{ MODEL-7 } \\
\hline Visualization $=1$ & 2.236 & 0.202 & 123.045 & 1 & 0.000 & {$\left[\begin{array}{ll}1.841 & 2.631\end{array}\right]$} \\
\hline Visualization $=2$ & 2.915 & 0.214 & 185.988 & 1 & 0.000 & {$\left[\begin{array}{ll}2.496 & 3.334\end{array}\right]$} \\
\hline Visualization $=3$ & 3.937 & 0.233 & 285.302 & 1 & 0.000 & {$\left[\begin{array}{ll}3.480 & 4.394\end{array}\right]$} \\
\hline Visualization $=4$ & 5.184 & 0.255 & 414.552 & 1 & 0.000 & {$\left[\begin{array}{ll}4.685 & 5.683\end{array}\right]$} \\
\hline Traditional & 0.571 & 0.086 & 44.166 & 1 & 0.000 & {$\left[\begin{array}{ll}0.402 & 0.739\end{array}\right]$} \\
\hline Tech. enabled & 0.844 & 0.082 & 105.083 & 1 & 0.000 & {$\left[\begin{array}{ll}0.683 & 1.006\end{array}\right]$} \\
\hline
\end{tabular}

Note: S.E.: Standard Error, df: Degree of freedom, CI: Confidence intervals

The authors predicted increases in the log odds with higher levels in innovation for people by 1.102 and 0.370 , respectively, for each one-unit increase in the independent variables. However, when it comes to business process innovations, the volumes for traditional and technology-enabled marketing tools are 1.147 and 0.185 , respectively. Moreover, when SMEs increase the usage of traditional and technology-enabled marketing tools by one unit, its ordered log odds of having innovation in visualization will increase by 0.571 and 0.844 , respectively, when holding other variables constant in the research model. Therefore, the probability of falling at higher levels on innovations in people, process, and visualization increases for SMEs with higher volumes in using traditional and technologyenabled marketing communication tools. Therefore, higher usage of these channels by SMEs makes them have more innovations in the components of marketing innovation. In this regard, all those arguments enable the authors to support H5a,b, H6a,b, and H7a,b hypotheses that contend the positive impact of traditional and technology-enabled marketing tools on innovations in people, process and visualization.

Table 5. Hypotheses Testing Results

\begin{tabular}{|l|l|}
\hline Hypotheses & Outcomes \\
\hline $\begin{array}{l}\text { H1a: The usage of traditional marketing communication tools positively } \\
\text { affects innovations in products/services. }\end{array}$ & Supported \\
\hline $\begin{array}{l}\text { H1b: The usage of technology-enabled marketing communication tools } \\
\text { positively affects innovations in products/services. }\end{array}$ & Supported \\
\hline $\begin{array}{l}\text { H2a: The usage of traditional marketing communication tools positively } \\
\text { affects innovations in prices. }\end{array}$ & Supported \\
\hline $\begin{array}{l}\text { H2b: The usage of technology-enabled marketing communication tools } \\
\text { positively affects innovations in prices. }\end{array}$ & Supported \\
\hline
\end{tabular}




\begin{tabular}{|l|l|}
\hline $\begin{array}{l}\text { H3a: The usage of traditional marketing communication tools positively } \\
\text { affects innovations in distribution. }\end{array}$ & Supported \\
\hline $\begin{array}{l}\text { H3b: The usage of technology-enabled marketing communication tools } \\
\text { positively affects innovations in distribution. }\end{array}$ & Supported \\
\hline $\begin{array}{l}\text { H4a: The usage of traditional marketing communication tools positively } \\
\text { affects innovations in promotion. }\end{array}$ & Supported \\
\hline $\begin{array}{l}\text { H4b: The usage of technology-enabled marketing communication tools } \\
\text { positively affects innovations in promotion. }\end{array}$ & Supported \\
\hline $\begin{array}{l}\text { H5a: The usage of traditional marketing communication tools positively } \\
\text { affects innovations in the people factor. }\end{array}$ & Supported \\
\hline $\begin{array}{l}\text { H5b: The usage of technology-enabled marketing communication tools } \\
\text { positively affects innovations in the people factor. }\end{array}$ & Supported \\
\hline $\begin{array}{l}\text { H6a: The usage of traditional marketing communication tools positively } \\
\text { affects innovations in processes. }\end{array}$ & Supported \\
\hline $\begin{array}{l}\text { H6b: The usage of technology-enabled marketing communication tools } \\
\text { positively affects innovations in processes. }\end{array}$ & Supported \\
\hline $\begin{array}{l}\text { H7a: The usage of traditional marketing communication tools positively } \\
\text { affects innovations in visualization. }\end{array}$ & Supported \\
\hline $\begin{array}{l}\text { H7b: The usage of technology-enabled marketing communication tools } \\
\text { positively affects innovations in visualization. }\end{array}$ & Supported \\
\hline
\end{tabular}

Source: Authors' own research results.

\section{Discussion}

This paper confirms the positive impact of marketing communication tools on the components of marketing innovation. For this reason, the results of this paper are compatible with the findings of some studies, since those studies prove the positive influences of the usage of marketing communication tools on innovations in product/service (Robul et al., 2020; Chia-Liang, 2018), price (Kizim et al., 2019), distribution (Bilovodska, 2017; Panasenko et al., 2021), promotion (Efremenko et al., 2020; Robul et al., 2020; Melnyk \& Golysheva, 2017), people (Armstrong et al., 2017; Chia-Liang, 2018), process (Falcones \& Castilla 2020; Luxton et al., 2015; Pisicchio \& Toaldo, 2020) and visualization (Cermak \& Reznicek, 2014; Robul et al., 2020; Fraccastoro et al., 2021).

The education level of executives might be a good reason to explain the positive impact of the usage of marketing communication tools on marketing innovation. For instance, more educated executives perform online marketing activities more than their less-educated counterparts (Deryabina \& Trubnikova, 2020), and more educated executives are better at performing marketing innovation activities than less educated executives (Soltani et al., 2015). Moreover, according to the research data, the majority of respondents are graduates of university. Thus, educated executives might have efficiently applied marketing communication tools that positively influenced their firms' marketing innovations.

When using marketing communication tools, culture is another determinant factor for firms (Fraccastoro et al., 2021). According to Hofstede Index (2021), the score of Slovakia for long-term orientation is high, and this fact is a sign of behavior that makes individuals shift traditions to new circumstances. In this regard, having this attitude might have made Slovakian executives implement new technologies in their marketing communications with traditional methods. Moreover, shifting their traditional marketing 
communication tools into technology-enabled marketing communication tools might have also made SMEs improve their innovativeness in marketing.

On the other hand, people quickly became more interested in online shopping because of social distancing processes and lockdowns in the Covid-19 pandemic (Pantano et al., 2020). As a result, the usage of online services has increased rapidly and has achieved top-level compared to the pre-Covid 19 periods (Kakushadze \& Liew, 2020). Furthermore, traditional marketing tools, such as direct marketing, personal selling, trade shows, and exhibitions, make marketing teams have close interactions with their customers and marketers have face-to-face meetings that cause Covid-19 spread. Thus, customers are less interested in searching for information about SMEs via traditional (offline) marketing communication tools, compared to technology-enabled (online) tools (Bačík et al., 2017). By being aware of these facts, many businesses, including SMEs, have also focused on using technology-enabled marketing tools to have more income during the Covid-19 pandemic. This fact might be another reason why the usage of technology-enabled marketing tools has also improved SMEs' innovative posture regarding marketing.

Although using traditional marketing tools is more expensive than technologyenabled marketing tools, SMEs still incur some costs when using technology-enabled marketing tools. Due to poor financial sources and the costs of the usage of these channels, the support policymakers and other essential financing institutions might provide for SMEs is a prerequisite for the development of innovative posture of SMEs. With this financial support, firms might be stimulated to take innovative actions when using technologyenabled and traditional communication channels that improve their marketing innovation. For instance, SMEs can make some investments in new technologies by working with artificial intelligence. As a result, their advertisements might become visible when people search their company in the first orders. Moreover, SMEs can place advertisements of their new products and services on the most visited websites. Hence, such businesses provide their innovativeness in the development of their products and their innovativeness in the usage of these marketing channels.

\section{Conclusion}

With the digital transformation, firms have become more visible and have performed more marketing activities. This is because technological changes have presented them with many new communication tools or have improved the traditional methods to contact their customers and meet their customers' demand. These channels might enable many benefits for firms to compete with their rivals, especially when performing innovative actions. In this regard, this paper aims at finding whether the usage of marketing communication tools by SMEs improves their innovativeness in the areas of marketing innovation or not. Thus, the research question might arise as follows: Does the usage of marketing communication tools improve the innovativeness of SMEs in the areas of marketing?

To answer this research question, the researchers applied the random sampling method to create a research sample. They collected data by employing a questionnaire survey that included questions regarding the usage of traditional and technology-enabled marketing tools by SMEs and their innovative posture regarding marketing, including innovativeness in products/services, prices, distribution, promotion, people, processes, and visualization. The researchers performed Ordinal Logistic Regression Tests to evaluate the responses of 812 Slovakian SMEs that completed the survey. The results of the analyses 
confirmed the positive impact of the usage of marketing communication tools on marketing innovations of SMEs. Characteristics of firm executives and cultural factors might be the reasons for those results. Furthermore, since SMEs encounter financial issues, they need financial support from the government and other financing institutions to perform their marketing operations effectively. Moreover, training that increases firm executives' and workers' ability, experience, and awareness regarding the usage of marketing communication tools might be beneficial for firms to implement efficient marketing strategies and methods in their operations.

\section{Theoretical implication}

This research makes contributions to the academic literature by providing empirical evidence on the role of traditional and technology-enabled marketing communication channels as strategic tools that increase innovativeness of SMEs in marketing. This paper also makes two different conceptual contributions. First, in contrast with other studies, this research has divided marketing communication tools into two constructs, i.e., traditional and technology enabled marketing tools, and has separately investigated the influence of these tools on innovations in marketing. Second, this study has also examined SMEs' innovativeness in various areas of marketing, namely, product, price, promotion, distribution, people, process, and visualizations. Since there is lack of comprehensive research in this specific topic and a unique construct, this study fills this research gap with these extensive considerations. Moreover, this research enables other authors to examine marketing innovation in a wider perspective and feel the differences or similarities in the impact of traditional and technology-enabled marketing tools on marketing innovation in detail. All those facts mentioned above are indicators of the uniqueness of this value creating research.

\section{Managerial implication}

Managers in SMEs will receive many benefits from the results and suggestions that this research provides for them. This is because this research highlights the importance of using traditional and technology-enabled marketing tools on firms' innovativeness that stimulate firms' competitiveness, growth and success. By doing so, this paper increases awareness and knowledge of managers regarding how to use these channels in practice. Moreover, this research sheds light on various areas of marketing in a wider scope, thus, managers might benefit from different strategic approaches although their firms might operate in different sectors, such as manufacturing and services. Since this paper analyzes SMEs in Slovakia, managers in countries that have similar socio-economic conditions might also apply the usage of these channels in their operations. On top of that, this research draws managers' attention to the negative consequences of the Covid-19 pandemic for their businesses, and expresses the significance of using technology-enabled marketing tools under these circumstances.

\section{Research limitations and Recommendation for further research}

Although this research has analyzed marketing communication tools and areas of marketing innovation in a widening scope, certain limitations arise in this research. For instance, this paper did not consider any characteristics of SMEs and their executives when analyzing marketing communication tools and innovation. Moreover, this paper was only 
limited to the SMEs segment, and all SMEs that this paper analyzed were from Slovakia. Since this paper also employed an online questionnaire, the willingness of survey respondents to complete the survey might be another limitation of this paper. However, the researchers provided a short survey that took a few minutes to complete. To have a more comprehensive study, researchers might investigate the impact of the characteristics of firms and firm executives when analyzing the relationship between marketing communication tools and marketing innovation. Moreover, since this paper only focuses on the SMEs segment and enterprises in Slovakia, further studies can also analyze larger enterprises and firms in different countries to extend the scope of their research.

\section{Acknowledgements}

This research was supported by the project VEGA 1/0813/19 "Managing the development of innovative and start-up forms of businesses in international environment and verification of INMARK concept", which has received funding from the Ministry of Education, Science, Research and Sport of the Slovak Republic.

\section{References}

Amirkhanpour, M., Vrontis, D., \& Thrassou, A. (2014). Mobile marketing: A contemporary strategic perspective. International Journal of Technology Marketing 5, 9(3), 252-269.

Amoah, J., Jibril, A.B., Luki, B.N., Odei, M.A. \& Yawson, C. (2021). Barriers of SMEs' sustainability in Sub-saharan Africa: a pls-sem approach. International Journal of Entrepreneurial Knowledge, 9(1), 10-24.

Bačík, R., Fedorko, R., Horváth, J., \& Mihál, J. (2017). The Analysis of the Perceived Usefulness of Online Communication Tools When Searching for SMEs. In International Conference on Strategic Innovative Marketing,131-136, Springer, Cham.

Barna, M., \& Semak, B. (2020). Main Trends of marketing innovations development of international tour operating. Baltic Journal of Economic Studies, 6(5), 33-41.

Bilovodska, 0. A. (2017). Marketing distributive and sales policy: research of essence, role and importance. Marketing and management of innovations, (2), 85-97.

Cant, M. C., \& Wiid, J. A. (2016). The use of traditional marketing tools by SMEs in an emerging economy: a South African perspective. Problems and perspectives in management, 14(1), 64-70.

Cermak, R., \& Reznicek, V. (2014). The implications of visualization of information on marketing management. In European Conference on Management, Leadership \& Governance (p. 410). Academic Conferences International Limited.

Chia-Liang, H. (2018). Innovating and diffusing internet commerce through user engagement: an empirical study of massively multiplayer online games. Innovation, DOI: $10.1080 / 14479338.2018 .1532295$

Cochran, W. G. (1963). Sampling Techniques, 2nd Ed., New York: John Wiley and Sons, Inc.

Cuevas-Vargas, H., Fernandez-Escobedo, R., Cortes-Palacios, H., A., \& Ramirez-Lemus, L. (2021). The relation between adoption of information and communication technologies and marketing innovation as a key strategy to improve business performance. Journal of Competitiveness, 13(2), 23-40.

Deryabina, G., \& Trubnikova, N. (2020). Digital B2B communications: economic and marketing effect. Lecture Notes in Networks and Systems, 87.

Dima, A.M., Ghinea, V. M. (2016). A model of Academic Leadership, Conference: 12th European Conference on Management, Leadership and Governance (ECMLG) 
Location: Natl Univ Polit Studies \& Publ Adm, Coll Management, Bucharest, ROMANIA. Proceedings of the Conference on European Management Leadership and Governance, pp. 61-70.

Dima, A.M, Vasilache, S. (2015). Social Network Analysis for Tacit Knowledge Management in Universities. Journal of the Knowledge Economy. 6(4). pp. 856-864.

Dvorsky, J., Belas, J., Cera, G., \& Bilan, S. (2021). Disparities in the perception of business risks in connection with the achieved education of the owner/manager and doing business. International Journal of Entrepreneurial Knowledge, 9(1), 25-40.

Efremenko, I., Panasenkova, T., \& Kalieva, O. (2020). Russian companies marketing activity transformation in foreign markets in the conditions of digitalization. In Proceedings of the International Scientific Conference-Digital Transformation on Manufacturing, Infrastructure and Service (1-7).

Falcones, W. A., \& Castilla, J. I. M. (2020). Factors affecting the implementation of innovation strategies in a dynamic environment: case SMES of the tourism sector in Ecuador. GCG: revista de globalización, competitividad y gobernabilidad, 14(2), 50-68.

Fraccastoro, S., Gabrielsson, M., \& Pullins, E. B. (2021). The integrated use of social media, digital, and traditional communication tools in the B2B sales process of international SMEs. International Business Review, 30(4), 101776.

Harrell, F. E. (2015). Regression Modeling Strategies: With Applications to Linear Models, Logistic and Ordinal Regression, and Survival Analysis, (2 $2^{\text {nd }}$ ed.), Springer.

Hofstede Index (2021), Retrieved from https://www.hofstede-insights.com/countrycomparison/slovakia/ Accessed on: 11.07.2021

Horvath, J., Gavurova, B., Bacik, R. \& Fedorko, R. (2021). Identification of uncertainty factors in the consumer behavior of the new generation of customers at the ecommerce level. Journal of Tourism and Services, 22(12), 168-183.

Kallier, S. M. (2017). The focus of marketing communication efforts of smes within south Africa. Management \& Marketing, 12(1), 140-154.

Kakushadze, Z. \& Liew, J. 2020. Coronavirus: Case for Digital Money? World Economics 21(1) (2020) 177-190. arXiv:2005.10154 [q-fin.GN]

Khan, M. A., Yasir, M. \& Khan, M. A. (2021). Factors affecting customer loyalty in the services sector of Pakistan. Journal of Tourism and Services, 22(12), 184-197.

Kizim, A. A., Pogosovna Kajfedzhan, D., Gayduk, V. I., Sekerin, V. D., \& Gorokhova, A. E. (2019). Specifics of choosing the modern communication technologies in Marketing and Logistics Based on innovative approaches. Dilemas Contemporáneos: Educación, Política y Valores, 7(1).

Kovanoviene, V., Romeika, G., \& Baumung, W. (2021). Creating value for the consumer through marketing communication tools. Journal of Competitiveness, 13(1), 59-75.

Kubickova, L., Kormanakova, M., Vesela, L., \& Jelinkova, Z. (2021). The implementation of industry 4.0 elements as a tool stimulating the competitiveness of engineering enterprises. Journal of Competitiveness, 13(1), 76-94.

Kurcheeva, G., \& Bakaev, M. (2017). Goal-oriented management in innovations' promotion with a website. Advances in Computer Science Research, 72, 216-222.

Luxton, S., Reid, M., \& Mavondo, F. (2015). Integrated marketing communication capability and brand performance. Journal of Advertising, 44(1), 37-46.

Malesev, S., \& Cherry, M. (2021). Digital and social media marketing-growing market share for construction SMEs. Construction Economics and Building, 21(1), 65-82.

Matúš, J., Matúšová, J. G., \& Findra, S. (2015). Innovation in marketing-marketing innovation. European Journal of Science and Theology, 11(6), 147-154.

Melnyk, Y. M., \& Golysheva, I. O. (2017). Features of the marketing complex in the system of innovative development of pharmaceutical companies. Marketıng And Management Of Innovations, (4), 27. 
Milichovský, F. (2017). An impact of reverse logistics activities on marketing communication. Acta Universitatis Agriculturae et Silviculturae Mendelianae Brunensis, 65(2), 669-678.

Panasenko, S. V., Cheglov, V. P., Ramazanov, I. A., Krasil'nikova, E. A., Stukalova, I. B., \& Shelygov, A. V. (2021). Improving the innovative development mechanism of the trade sector. Journal of Advanced Pharmacy Education \& Research| Jan-Mar, 11(1).

Pantano, E., Pizzi, G., Scarpi, D. \& Dennis, C. (2020). Competing during a pandemic? Retailers' ups and downs during the COVID-19 outbreak. J Bus Res, 116, 209-213.

Papa, A., Dezi, L., Gregori, G.L., Mueller, J. \& Miglietta, N. (2020). Improving innovation performance through knowledge acquisition: the moderating role of employee retention and human resource management practices. Journal of Knowledge Management, 24(3), 589-605.

Pisicchio, A. C., \& Toaldo, A. M. M. (2020). Integrated marketing communication in hospitality SMEs: analyzing the antecedent role of innovation orientation and the effect on market performance. Journal of Marketing Communications, 1-20.

Ramasobana, M., Fatoki, O., \& Oni, O. (2017). Entrepreneurs' characteristics and marketing communication practices of SMEs in South Africa. Gender and Behaviour, 15(3), 93509371.

Robul, Y., Lytovchenko, I., Tchon, L., Nagornyi, Y., Khanova, O., \& Omelianenko, O. (2020). Digital marketing tools in the value chain of an innovative product. International Journal Of Scientific \& Technology Research, 9(4).

Soltani, S., Azadi, H., Hosseini, S. J. F., Witlox, F., \& Passel, S. V. (2015). Marketing innovation in rural small food industries in Iran. Journal of Food Products Marketing, 21(5), 533551.

Taiminen, H. M., \& Karjaluoto, H. (2015). The usage of digital marketing channels in SMEs. Journal of Small Business and Enterprise Development, 22(4), 633-651.

Tekin, Ö. A., \& Turhan, A. A. (2020). Does social media addiction differ by personality traits? A study on undergraduate tourism students. Journal of Tourism and Services, 22(12), 23-41.

Wardati, N. K., \& Mahendrawathi, E. R. (2019). The impact of social media usage on the sales process in small and medium enterprises (SMEs): A systematic literature review. Procedia Computer Science, 161, 976-983.

Zaušková, A., Bezáková, Z., \& Grib, L. (2015). Marketing communication in eco-innovation process. Procedia Economics and Finance, 34, 670-675.

Ziółkowska, M. J. (2021). Digital Transformation and marketing activities in small and medium-sized enterprises. Sustainability, 13(5), 2512. 